\title{
Ultrastructure of Helicobacter trogontum in culture and in the gastrointestinal tract of gnotobiotic mice
}

\author{
SílVIA B. MOURA, E. N. MENDES*, DULCIENE M. M. QUEIROZ*, ELIZABETH R. S. \\ CAMARGOS $\uparrow$, M. EVANGELINA F. FONSECA $\$$, G. A. ROCHA* and J. R. NICOLI
}

Department of Microbiology, Instituto de Ciências Biológicas, Universidade Federal de Minas Gerais, * Laboratory of Research in Bacteriology, Faculdade de Medicina, †Department of Morphology, Instituto de Ciências Biológicas, Universidade Federal de Minas Gerais and †Electron Microscopic Unit, Instituto de Microbiologia, Universidade Federal do Rio de Janeiro, Brazil

\begin{abstract}
Helicobacter trogontum is a micro-aerophilic urease-positive bacterium that has recently been isolated from the intestinal mucosa of rats. The purpose of this investigation was to study the ultrastructural details of this micro-organism in both pure culture and in the gastrointestinal tract of germ-free mice infected with $\boldsymbol{H}$. trogontum. The micro-organism was a fusiform to slightly spiral gram-negative cell, $4-6 \mu \mathrm{m}$ long and 0.6-0.7 $\mu \mathrm{m}$ wide, with four to seven bipolar sheathed flagella. The cytoplasm presented several irregular and also globular granules. On each side of the polar regions of the cells, there was a highly electron-dense band, the 'polar membrane'. Coccoidal forms were seen in old cultures. $\boldsymbol{H}$. trogontum showed several ultrastructural characteristics of the Helicobacter genus and much resemblance to $H$. rappini and $H$. bilis. $H$. trogontum mainly colonised the large bowel of the gnotobiotic mice where it could be seen in the lumen and also inside the enterocytes. Vacuolation of the ileal epithelial cells, loss of microvilli and pronounced desquamation of the enterocytes of the caecum were observed in the bowel colonised by the bacterium. These observations raise the possibility that $\mathrm{H}$. trogontum could cause some harm to the host at least in particular circumstances such as when it colonises the gastrointestinal tract of a germ-free host.
\end{abstract}

\section{Introduction}

Helicobacter pylori is a curved, gram-negative bacterium that colonises the gastric mucosa of man [1]. Currently, H. pylori is implicated as an agent of chronic gastritis and peptic ulcer disease and also as an important factor in the pathogenesis of gastric adenocarcinoma and MALT lymphoma [2-5]. Since the discovery of this micro-organism the genus Helicobacter has been expanding rapidly and, because of the interest in understanding the association between $H$. pylori and gastroduodenal disease, other members of the genus have received increasing attention in comparative studies. For rodents, seven Helicobacter species have been identified: $H$. muridarum [6], $H$. hepaticus [7], $H$. bilis [8], Flexispira rappini (that has been reclassified as a member of the genus Helicobacter [9]), H. cholecystus [10] and, more recently, $H$. trogontum [11] and $H$.

Received 25 Sept. 1997; accepted 14 Oct. 1997.

Corresponding author: Dr D. M. M. Queiroz. rodentium [12]. There is also a report suggesting that the human pathogen $H$. cineadi is a natural inhabitant of the intestinal tract of hamsters [13].

Unlike H. pylori and some other gastric helicobacters, the species observed in rodents seem not to cause disease when they are in their natural habitats and they are considered part of the normal microbiota of the intestine, although some of them can be related to disease when found at other sites in the host $[7,8,14,15]$.

Morphological studies of new Helicobacter spp. reveal novel and also common structures of the genus, providing clues about what features are likely to be involved in the colonisation of the gastrointestinal mucosa and in the causation of disease [16].

$H$. trogontum has been described recently and there is little information about the ultrastructure of this organism [11]. Therefore, the purpose of this investigation was to study the ultrastructural details of $H$. trogontum in pure culture and in the gastrointestinal 
tract of germ-free mice infected with the microorganism.

\section{Materials and methods}

\section{In-vitro study}

The type strain of $H$. trogontum (ATCC 700114) was grown on sheep blood agar $10 \%$ for $1-7$ days at $37^{\circ} \mathrm{C}$ in micro-aerophilic conditions.

Negative staining. Colonies from a 48-h culture were


obtain a heavy suspension of bacteria. One drop of the mixture was applied to a formvar-coated 300-mesh copper grid for $1 \mathrm{~min}$. Excess fluid was removed and replaced with a drop of phosphotungstic acid $1 \% \mathrm{w} / \mathrm{v}$, $\mathrm{pH}$ 6.5, for 20-30 s and examined with a Zeiss E.M. 10.

Ultra-thin sections. After incubation for 1, 2, 3, 5 and 7 days, the colonies were harvested from plates, separately transferred to saline $0.85 \%$ to obtain a heavy mixture and centrifuged at low speed. The pellets obtained were fixed in glutaraldehyde $2.5 \% \mathrm{v} / \mathrm{v}$ buffered with $0.1 \mathrm{M}$ sodium cacodylate, $\mathrm{pH} 7.2$, for $1 \mathrm{~h}$ at room temperature and gently washed three times (10 min each) in sodium cacodylate $0.1 \%$. The pellets were then carefully included in agar $2 \%$, post-fixed in osmium tetroxide $1 \% \mathrm{w} / \mathrm{v}$ buffered with $0.1 \mathrm{M}$ sodium cacodylate, $\mathrm{pH} 7.2$, for $40 \mathrm{~min}$ at room temperature, washed with $0.1 \mathrm{M}$ sodium cacodylate and dehydrated in a graded alcohol series for Epon embedding. Ultrathin sections were collected on 300-mesh copper grids, stained with uranyl acetate $5 \% \mathrm{w} / \mathrm{v}$ for $10 \mathrm{~min}$ and lead citrate for $5 \mathrm{~min}$ and examined with a Zeiss E.M. 10.

\section{In-vivo study}

Three 4-week-old germ-free mice (NIH, Taconic, Germantown, USA) were inoculated orally with a heavy suspension of the type strain of $H$. trogontum (ATCC 700114) and maintained in micro-isolator cages under sterile conditions for 3 weeks, after which they were killed by spinal dislocation. Fragments from the antral and oxyntic mucosa of the stomach and from the mucosa of the duodenum, jejunum, ileum, caecum and colon were washed separately in sterile saline $0.85 \%$ for microbiological and ultrastructural studies.

Microbiological evaluation. Two mucosal fragments from each region of the stomach and of the intestine were employed for the urease test and for carbol fuchsin-stained smears. One specimen was smeared on to a glass slide, heat-fixed, stained with carbol fuchsin and examined under oil immersion lens for the presence of fusiform to slightly spiral bacteria. For the urease test, the specimen was inserted into Christensen's urea agar. The test was considered positive when the colour of the medium changed from amber to pink within $12 \mathrm{~h}$.
Ultrastructural evaluation. Fragments from each region of the gastric and intestinal mucosa were immediately fixed in glutaraldehyde $2.5 \% \mathrm{v} / \mathrm{v}$ buffered with $0.1 \mathrm{M}$ sodium cacodylate, $\mathrm{pH} 7.2$, for $3 \mathrm{~h}$ at room temperature, and placed in three changes of $0.1 \mathrm{M}$ sodium cacodylate, $\mathrm{pH} \mathrm{7.2,} \mathrm{for} 10 \mathrm{~min}$ each. The fragments that were considered to be $H$. trogontum-positive by the two microbiological tests were processed as described above for ultra-thin sections of $H$. trogontum culture.

Fragments from each region of the gastric and of the intestinal mucosa of non-infected germ-free mice were also employed for ultrastructural evaluation.

\section{Results}

In-vitro study

Light microscopic examination of carbol fuchsinstained smears from 24-48-h cultures of $H$. trogontum showed fusiform to slightly curved cells with granules that appeared larger than the width of the organism. These granules showed metachromasia when stained with toluidine blue. After incubation for 3 days the granules were found less frequently and there were some coccoidal cells. Colonies of 5-7-day-old cultures showed almost exclusively coccoidal forms.

Electron microscopic examination showed that the morphology of $H$. trogontum resembled that of $H$. rappini and $H$. bilis. In negatively stained preparations, $H$. trogontum was seen as a fusiform to a slightly curved cell, 4-6 $\mu \mathrm{m}$ long and $0.6-0.7 \mu \mathrm{m}$ wide, with four to seven sheathed flagella at both ends and periplasmic fibres that were coiled around the length of the cell giving a criss-cross appearance to the bacterium (Fig. 1).

Ultra-thin sections of the micro-organism showed the typical ultrastructure of gram-negative organisms with an outer membrane and a plasma membrane separated by a periplasmic space. The organism was slightly tapered towards the ends of the cell and the sites of the insertion of flagella were flattened (Fig. 2A). On each side of the polar regions of the cells, there was a highly electron-dense band, the 'polar membrane', that was closely adherent to the plasma membrane (Fig. 2B). The cytoplasm was granular with a large number of ribosomes, several irregular and also spherical granules (Fig. 2B and $\mathrm{C}$ ). These granules were seen more frequently in $24-48-\mathrm{h}$ cultures.

Dividing cells were easily seen in cultures incubated for $24-48 \mathrm{~h}$. Atypical or coccoidal forms of $H$. trogontum were seen in 4-day-old or older cultures (Fig. 2D).

\section{In-vivo study}

The microbiological tests were negative in the fragments obtained from the stomach of the infected 


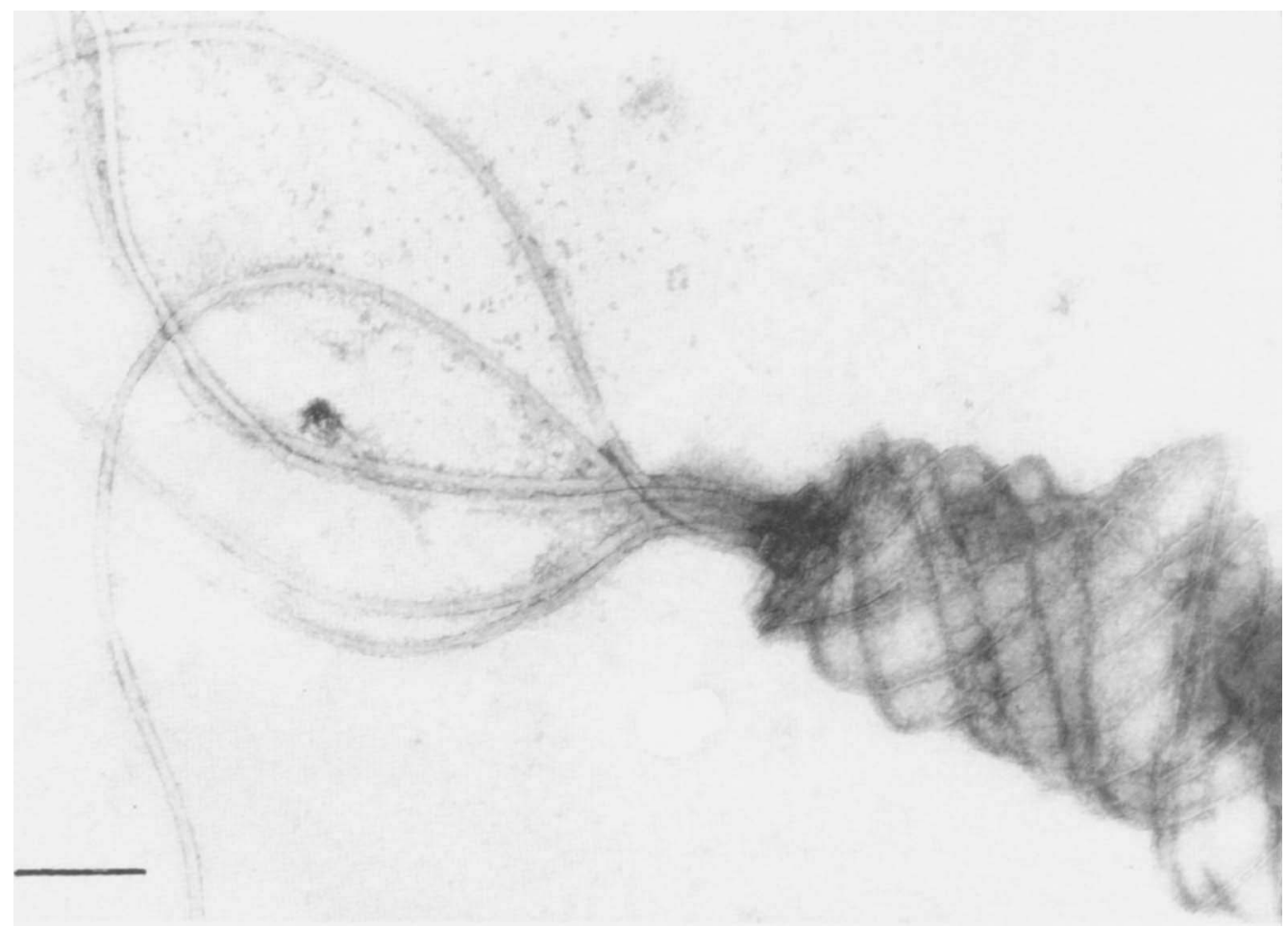

Fig. 1. Negative staining of a 2-day-old culture of $H$. trogontum showing a tuft of flagella and the periplasmic fibres (bar $=0.25 \mu \mathrm{m})$.

mice. Although the urease test was positive with samples from the duodenum and jejunum of the animals, it was not possible to detect either bacteria or any apparent cellular alteration in these regions of the bowel by electron microscopy.

In contrast, although bacteria were only rarely present in the ileum, a large number of vacuoles were observed in the epithelial cells (Fig. 3A and B). In the caecum, numerous bacteria were seen both in the lumen (Fig. 4A) and inside the enterocytes where they were observed isolated or mostly in clusters in the cytoplasm (Fig. 4B). The clusters consisted of a variable number of bacteria and were frequently localised near the nucleus of the cells (Figs. 4B and 5A). Also, pronounced desquamation and loss of microvilli were observed in this region in infected animals (Fig. 5A, B and C). Structures of different sizes and densities were consistently seen in the cytoplasm of the epithelial cells of the ileum, caecum and colon (Figs. 3A, 4B and 5). Bacteria were infrequently observed in the colon, where less evident alterations were found (Fig. 5D).

\section{Discussion}

As the Helicobacter genus has been defined primarily on genotypic rather than on phenotypic grounds, it comprises species that are ultrastructurally very diverse [16]. Some of the characteristics that are shared by almost all members of the genus are the typical cell wall structure of gram-negative bacteria, the cytoplasm with intracellular granules, the presence of polar sheathed flagella, the 'polar membrane' in the terminal region of the organism that seems to be related to energy production for movement, and alteration to the coccoidal form in old cultures [16]. In addition to these features, $H$. trogontum has an arrangement of periplasmic fibres and bipolar tufts of sheathed flagella resembling those of $H$. muridarum, $H$. rappini and $H$. bilis. With the exception of $H$. muridarum, which has a helically coiled body, the other two are also straight to slightly curved fusiform bacteria.

It has been postulated that the spiral shape and the active flagella enable the Helicobacter species to move easily in a viscous environment such as the mucus of the gastrointestinal tract [17]. It is possible that the periplasmic fibres coiled around the length of the fusiform helicobacters may also be related to motility, as the ridges formed by them could increase torque in the mucus or the fibres themselves could be contractile and produce rotation of the cell $[6,16]$.

H. trogontum presented prominent intracellular granules of different shapes, as has been observed in other species of this genus [16, 18]. The nature of these granules differs in different prokaryotic organisms, but they almost always function in the storage of energy or serve as a reservoir of structural building blocks [19]. The positive metachromatic staining of the 



Fig. 2. Ultra-thin sections of $H$. trogontum culture. A, detail of a tip of the bacterium showing the cell wall and the flattened end of the cell $($ bar $=0.1 \mu \mathrm{m}) ; \mathbf{B}$, the 'polar membrane' (arrow) and granules (bar $=0.1 \mu \mathrm{m})$; $\mathbf{C}$, two cells longitudinally sectioned showing the serrated appearance of the micro-organism contour given by the periplasmic fibres and the granular cytoplasm with irregular and spherical granules (bar $=0.5 \mu \mathrm{m}) ; \mathbf{D}$, coccoidal form of a 4-day-old $H$. trogontum culture (bar $=0.25 \mu \mathrm{m}$ ). 

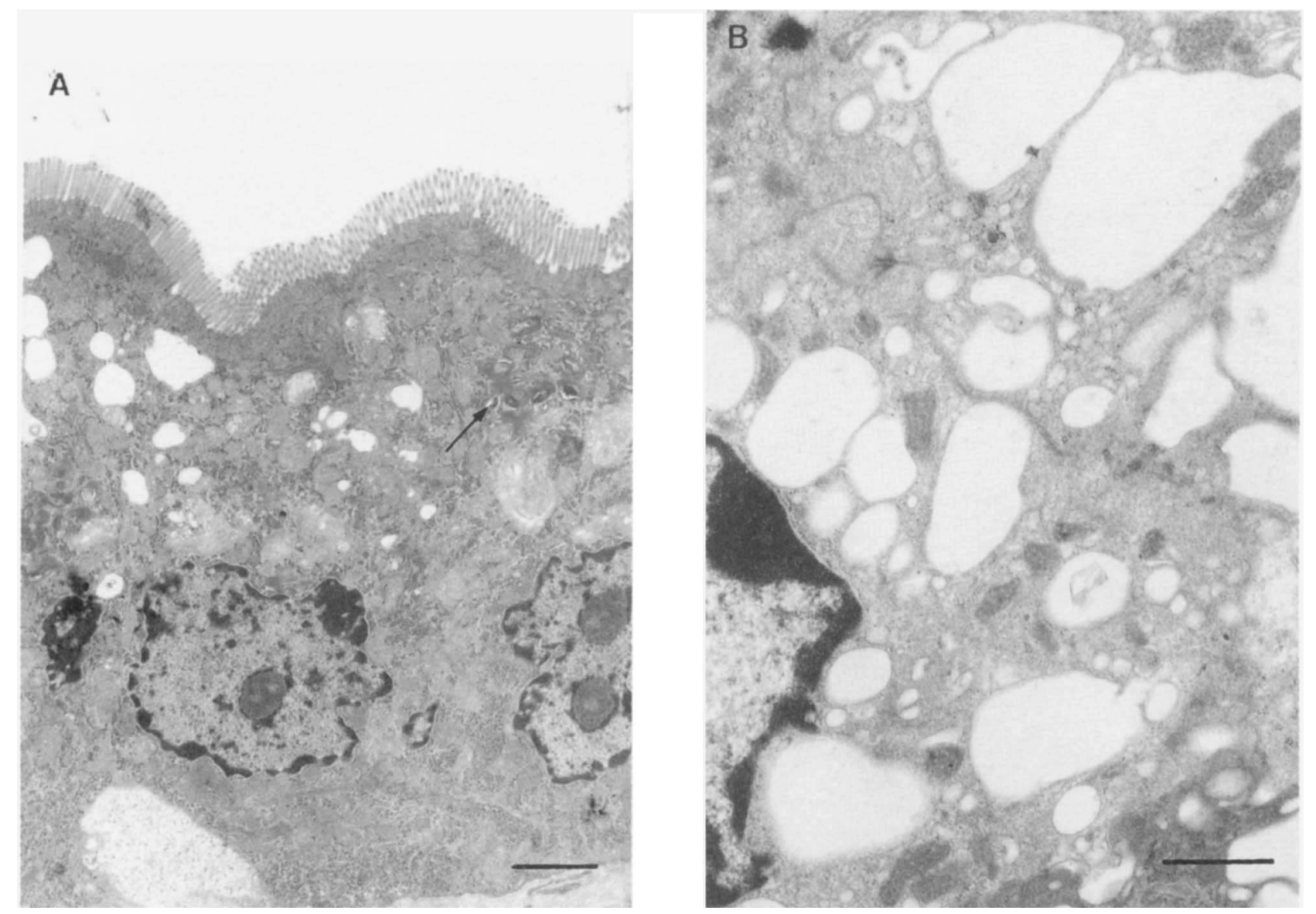

Fig. 3. Ultra-thin section of the ileum of a $H$. trogontum-positive mouse. A, pronounced vacuolation and structures with different densities (arrow) in the cytoplasm of the epithelial cell (bar $=2.0 \mu \mathrm{m}) ; \mathbf{B}$, higher magnification of vacuoles $($ bar $=1.0 \mu \mathrm{m})$.

H. trogontum granules suggests that they contain polyphosphate.

Although species that resemble $H$. trogontum, such as $H$. muridarum, $H$. rappini and $H$. bilis, are considered natural inhabitants of the intestine of rodents, they seem to have the ability to elicit disease when found at other anatomical sites of the host or in other host species. H. muridarum has occasionally been observed in the gastric mucosa of mice and rats where its presence is associated with gastritis $[15,16,20] . H$. bilis colonises, besides the lower intestine, the bile and liver of aged inbred mice and is associated with multifocal chronic hepatitis [8]. H. rappini is a normal inhabitant of the intestinal mucosa of mice, but has also been isolated from aborted sheep fetuses and stools of humans with chronic diarrhoea [14]. Another rodent species that is also associated with disease is $H$. hepaticus [7]. Although not sharing many morphological characteristics with $H$. trogontum, $H$. hepaticus is most closely related to it on the basis of $16 \mathrm{~S}$ rRNA sequence analysis [11].

Investigations are required, to determine whether $H$. trogontum, like these other rodents species, is potentially virulent and, under certain circumstances, has the ability to colonise other anatomical regions of the gastrointestinal tract besides the colon in its natural host.

In gnotobiotic mice inoculated with $H$. trogontum, the bacterium could be detected in the small and large bowel. Another study with a larger number of animals is in progress in our laboratory to elucidate the pattern of $H$. trogontum colonisation and the histopathological changes it can induce in the gastrointestinal tract of gnotobiotic mice.

Several clusters of bacteria were seen inside the enterocytes, mainly in the caecum of the gnotobiotic animals. Tissue invasion by helicobacters has seldom been reported [21, 22]. H. pylori has been identified within the lamina propria of gastric epithelium, but mucosal invasion is rare [23]. Endocytosed bacteria in gastric mucosa were well documented in one ultrastructural study of $H$. mustelae in the ferret [24]. In a study by Phillips and Lee [25] on the pattern of colonisation of a spiral bacterium (lately classified as $H$. muridarum) in the intestine of conventional and gnotobiotic rodents, intracellular organisms were consistently seen only in the intestinal tissues of the latter. The authors have hypothesised that this phenomenon 

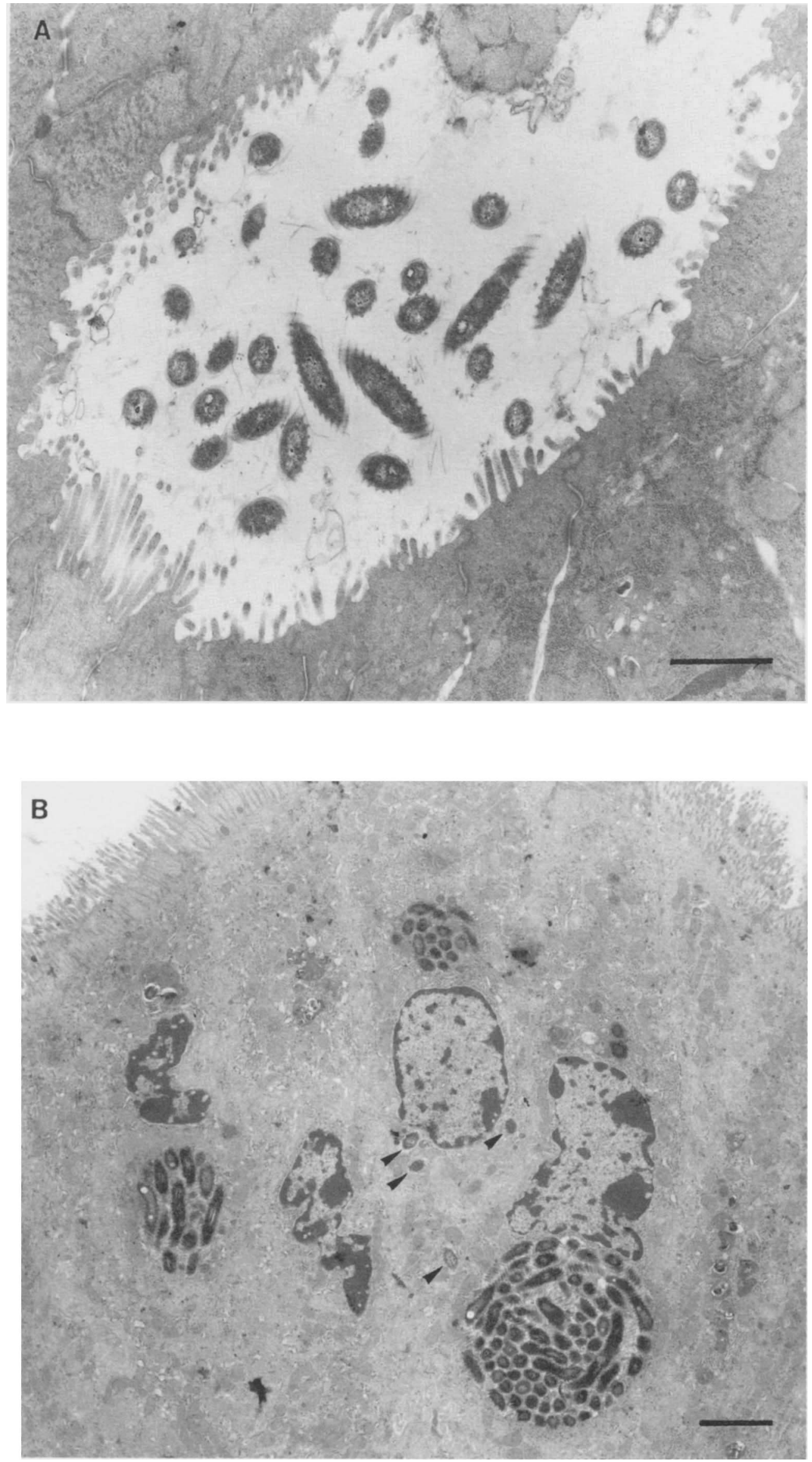

Fig. 4. Electron micrography of the caecum of an infected mouse showing: A, H. trogontum within the lumen of a gland $($ bar $=1.0 \mu \mathrm{m}) ; \mathbf{B}$, bacteria in clusters and free (arrowheads) in the cytoplasm of the epithelial cells (bar $=$ $2.0 \mu \mathrm{m})$. 



Fig. 5. Ultra-thin section of the caecum $(\mathbf{A}, \mathbf{B}, \mathbf{C})$ and the colon $(\mathbf{D})$ of a mouse infected with $H$. trogontum showing: A, a bacterial cluster occupying the entire cytoplasm and dislodging the nucleus to the top of the cell, note the loss of microvilli of the neighbouring cell $($ bar $=5.0 \mu \mathrm{m}) ; \mathbf{B}$, degenerated cell without microvilli, presenting a pycnotic nucleus and structures with different shapes and densities (bar $=5.0 \mu \mathrm{m}) ; \mathbf{C}$, damaged cell with several bacteria free (arrowhead) in cellular debris and structures with different densities (arrow) (bar $=2.0 \mu \mathrm{m}$ ); $\mathbf{D}$, transverse section of a bacterium on the surface of a colon enterocyte $(\mathrm{bar}=1.0 \mu \mathrm{m})$. 
may occur either as a consequence of bacterial overgrowth leading to increased tissue invasion or as a consequence of the reduced defence mechanisms of gnotobiotic hosts. This could also be an explanation for the intracellular bacteria observed in the present study. However, the alterations in epithelial cells of the intestine, as well as the tissue invasion by the bacteria, observed in the present study seemed to be more pronounced than those reported by Phillips and Lee [25].

Intense vacuolation of the epithelial cells of the ileum were observed. Vacuolation has also been observed in cells of the antral mucosa of $H$. pylori-positive patients [26, 27]. As a subset of $H$. pylori strains expresses a cytotoxin that induces cellular vacuolation in a number of different epithelial cell lines in vitro [28], it is important to investigate whether $H$. trogontum has the ability to produce a similar virulence factor. Other degenerative changes that have been observed in the gastric mucosa colonised by $H$. pylori [27], such as loss of microvilli and increased epithelial cell desquamation, were also observed in the large bowel of $H$. trogontum-positive mice.

These observations suggest that $H$. trogontum, although probably part of the indigenous microbiota of the colonic mucosa of rats, may have the ability to cause harm to the host under certain conditions, as demonstrated in the present study, where $H$. trogontum colonised the gastrointestinal tract of a germ-free host.

This work was supported by grants from CNPq, FINEP and FAPEMIG, Brazil. We are indebted to the Center for Electron Microscopy (CEMEL) of Instituto de Ciências Biológicas, Universidade Federal de Minas Gerais (UFMG) for the use of its facilities and to Professor Virginia H. R. Leite from the Electron Microscopy Center of Faculdade de Medicina, UFMG.

\section{References}

1. Marshall BJ, Warren JR. Unidentified curved bacilli in the stomach of patients with gastritis and peptic ulceration. Lancet 1984; 1: $1311-1315$.

2. Blaser MJ. Helicobacter pylori and the pathogenesis of gastroduodenal inflammation. $J$ Infect Dis 1990; 161: 626-633.

3. Graham DY, Go MF. Helicobacter pylori: current status. Gastroenterology 1993; 105: 279-282.

4. Parsonnet J, Friedman GD, Vandersteen DP et al. Helicobacter pylori infection and the risk of gastric carcinoma. $N$ Engl $J$ Med 1991; 325: 1127-1131

5. Wotherspoon AC, Doglioni C, Diss TC et al. Regression of primary low-grade B-cell gastric lymphoma of mucosaassociated lymphoid tissue type after eradication of Helicobacter pylori. Lancet 1993; 342: 575-577.

6. Lee A, Phillips MW, O'Rourke JL et al. Helicobacter muridarum sp. nov., a microaerophilic helical bacterium with a novel ultrastructure isolated from the intestinal mucosa of rodents. Int J Syst Bacteriol 1992; 42: 27-36.

7. Fox JG, Dewhirst FE, Tully JG et al. Helicobacter hepaticus sp. nov., a microaerophilic bacterium isolated from livers and intestinal mucosal scrapings from mice. J Clin Microbiol 1994; 32: $1238-1245$
8. Fox JG, Yan LL, Dewhirst FE et al. Helicobacter bilis sp. nov., a novel Helicobacter species isolated from bile, livers, and intestines of aged, inbred mice. J Clin Microbiol 1995; 33: $445-454$.

9. Vandamme $\mathrm{P}$, Falsen E, Rossau $\mathrm{R}$ et al. Revision of Campylobacter, Helicobacter, and Wolinella taxonomy: emendation of generic descriptions and proposal of Arcobacter gen. noy, Int J Syst Bacteriol 1991; 41: 88-103.

10. Franklin CL, Beckwith CS, Livingston RS et al. Isolation of a novel Helicobacter species, Helicobacter cholecystus sp. nov., from the gallbladders of Syrian hamsters with cholangiofibrosis and centrilobular pancreatitis. J Clin Microbiol 1996; 34: 2952-2958.

11. Mendes EN, Queiroz DMM, Dewhirst FE, Paster BJ, Moura $\mathrm{SB}$, Fox JG. Helicobacter trogontum sp. nov., isolated from the rat intestine. Int $J$ Syst Bacteriol 1996; 46: 916-921.

12. Shen Z, Fox JG, Dewhirst FE et al. Helicobacter rodentium sp. nov., a urease-negative Helicobacter species isolated from laboratory mice. Int J Syst Bacteriol 1997; 47: 627-634

13. Gebhart CJ, Fennell CL, Murtaugh MP, Stamm WE. Campylobacter cinaedi is normal intestinal flora in hamsters. $J$ Clin Microbiol 1989; 27: 1692-1694.

14. Schauer DB, Ghori N, Falkow S. Isolation and characterization of "Flexispira rappini" from laboratory mice. J Clin Microbiol 1993; 31: 2709-2714

15. Queiroz DMM, Contigli C, Coimbra RS et al. Spiral bacterium associated with gastric, ileal and caecal mucosa of mice. Lab Anim 1992; 26: 288-294.

16. Lee A, O'Rourke J. Ultrastructure of Helicobacter organisms and possible relevance for pathogenesis. In: Goodwin CS, Worsley BW (eds) Helicobacter pylori. Biology and clinical practice. Boca Raton, FL, CRC Press. 1993: 15-36.

17. Bode G, Malfertheiner P, Ditschuneit H. Pathogenetic implications of ultrastructural findings in Campylobacter pylori related gastroduodenal disease. Scand J Gastroenterol 1988; 23 Suppl 142: $25-39$.

18. Bode G, Mauch F, Ditschuneit H, Malfertheiner P. Identification of structures containing polyphosphate in Helicobacter pylori. J Gen Microbiol 1993, 139: 3029-3033.

19. Brock TD, Madigan MT, Martinko JM, Parker J. Cell biology In: Biology of microorganisms, 7th edn. New Jersey, Prentice Hall. 1994: 43-88.

20. Lee A, O'Rourke J. Gastric bacteria other than Helicobacter pylori. Gastroenterol Clin North Am 1993; 22: 21-42.

21. Zeller J, Takeuchi A. Infection of the colon of the rhesus monkey by spiral-shaped organisms. Vet Pathol 1982; 19 Suppl 7: 26-32.

22. Dubois A, Fiala N, Heman-Ackah LM et al. Natural gastric infection with Helicobacter pylori in monkeys: a model for spiral bacteria infection in humans. Gastroenterology 1994; 106: $1405-1417$.

23. Sherman PM. Adherence and internalization of $H$. pylori by epithelial cells. In: Hunt RH, Tytgat GNJ (eds) Helicobacter pylori. Basic mechanisms to clinical cure. Dordrecht, Kluwer Academic Publishers. 1993: 148-162.

24. O'Rourke J, Lee A, Fox JG. An ultrastructural study of Helicobacter mustelae and evidence of a specific association with gastric mucosa. J Med Microbiol 1992; 36: 420-427.

25. Phillips MW, Lee A. Isolation and characterization of a spiral bacterium from the crypts of rodent gastrointestinal tracts. Appl Environ Microbiol 1983; 45: 675-683.

26. Bode G, Malfertheiner P, Lehnhardt G, Ditschuneit $H$. Virulence factors of Helicobacter pylori - ultrastructural features. In: Malfertheiner P, Ditschuneit H (eds) Helicobacter pylori, gastritis and ulcer. Berlin, Springer-Verlag. 1990: 63-73.

27. Ogata $T$, Araki K. Electron microscopic study of the morphological changes of gastric mucus cell induced by Helicobacter pylori in human gastric ulcers. $J$ Submicrosc Cytol Pathol 1996; 28: 255-264.

28. Cover TL, Cao P, Lind CD, Tham KT, Blaser M. Correlation between vacuolating cytotoxin production by Helicobacter pylori isolates in vitro and in vivo. Infect Immun 1993; 61: 5008-5012. 